\title{
Women, New Music and the Composition of Becomings
}

\author{
SALLY MACARTHUR
}

UNIVERSITY OF WESTERN SYDNEY

Outmoded patterns of thought, to invoke Deleuze, plague the practices and discourses of 'new' classical music. ${ }^{1}$ Such a claim may seem absurd given 'new' music has earned a reputation for being unorthodox, experimental and subversive, and characterised by a mindset preoccupied with musical progress, complexity and historical necessity. ${ }^{2}$ In this essay I shall argue that despite the plethora of styles which now seem to embody 'new' music, it has become increasingly repetitive, and locked into static conventions for its presentation and composition. ${ }^{3}$ This is due, in part, to the recent emphasis given to its entrepreneurial activities but, as I will also show, the resistance of organisations to programming women's music means that a whole dimension that might be opened up as 'new' continues to escape our notice.

The reputation of the music-in which the widespread belief is that it occupies musical territory marked by violence, discord and a hostile sound-worldmeans that it struggles to attract large audiences. It is imagined as music that is not easy on the ear, and listeners frequently complain that it is incomprehensible with some even suggesting that it is noise, not music. ${ }^{4}$ Such an idea was made clear to me 
in the early 1990s when I worked as the music officer for the Australian chamber music organisation Musica Viva. To minimise the possibility of audiences leaving in droves at the interval break, Musica Viva adopted the practice of programming the new, thus unfamiliar, work before the interval break. It assumed that if audiences were forced to listen to the music, they would gradually develop a palate for it. But mainstream audiences have long resisted 'new' music, no matter how hard the classical music organisations have tried to introduce it. Linda Dusman makes the point that audiences who regularly attend 'classical' concerts of historic music are less likely to attend 'new' music concerts. ${ }^{5}$

Audiences for 'new' music consist mostly of practitioners and they tend to be small in number.6 'New' music composers are simultaneously fringe-dwellers and members of the avant-garde where they gather prestige. ${ }^{7}$ While 'new' music of the serialist persuasion prizes itself as a rational discourse-for Susan McClary, 'a cluster of puzzles to be solved painstakingly in seminars's - to the ear it can sound disordered and irrational. According to McClary, the gendered implications of 'new' music's irrationality give rise to its practitioners' 'emphatic posturing about Difficulty'. ${ }^{9}$ While 'new' music is also postmodern, implying that it is 'tonal' (and to that extent 'easier on the ear'), it is rarely mistaken for other types of music such as popular music. By and large, 'new' music seems inaccessible, complex and difficult when compared to popular music. ${ }^{10}$ According to McClary, however, when 'new' music became institutionalised in the mid-twentieth century, safely couched in the academy, it began to lose its disruptive edge. To misquote McClary slightly, 'new' music has come to play the game of 'Difficulty For Its Own Sake'.11 In this view, music 'that announces Difficulty as its raison d'être does not subvert'.12

The neoliberal structures which organise 'by drawing strict boundaries, creating binary oppositions and dividing space into rigid segments with a hierarchical structure' are alive and well in the places inhabited by 'new' music practitioners. ${ }^{13}$ Like McClary, I argue that this music no longer transgresses the conventions of tonality or technical 'difficulty', a hallmark of its performance practice, but is, instead, maintaining what has long since become the status quo. ${ }^{14}$ The 'end-product' - the musical composition and the musical performance-and the individualised 'entrepreneurial subject' are core to 'new' music's modus operandi. These are constructs, however, founded on old ways of thinking which have become 
deeply entrenched and self-perpetuating. Rapid technological changes have impacted on music as much as elsewhere in the new convergent media age. In the 'new' music scene, the entrepreneurial discourse that self-consciously and uncritically celebrates 'new' music's 'edginess' is contradicted by a set of anachronistic practices that belong in the nineteenth century. I will argue that women's music lacks a performance venue because it fails to conform to these preestablished structures. I will also investigate the political and ideological patterns at work that serve the interests of particular groups and inhibit others.

In the turbulent sea of 'new' music, the waves that carried women's music onto the concert platform have receded. ${ }^{15}$ The empirical research indicates a decrease from approximately two per cent to one per cent in women's classical music being performed on concert platforms in Australia, the United Kingdom and North America. ${ }^{16}$ A recent survey of six tertiary music institutions in Australia suggests that very little music by women is taught in the theoretical subjects, which leads to their significant under-representation in the concert hall.17 Yet, more women are studying musical composition and more women composers are represented by the Australian Music Centre (AMC). ${ }^{18}$ If the number of women composers has increased in tertiary music institutions and at the AMC, why is this not being reflected in the concert hall?

A critique of the 'woman composer' question demonstrates the continued relevance of sexual difference despite the anti-essentialist line which argues for a type of subjectivity which is 'post-gender' or 'beyond-gender'. I argue that the discourses associated with 'new' music impact negatively on women composers. Borrowing from Rosi Braidotti, I will briefly examine four of these: 'hierarchical difference', 'gender-mainstreaming', 'exceptional woman', and 'entrepreneurship'.19

My central argument is an echo of Richard Toop who asserted that by vastly increasing the number of Australian composers gaining official recognition we have created a 'cultural disaster'. In Toop's view, aesthetic distinctiveness in music has been muzzled because too many composers are competing for the same recognition and the same small 'pot of money'. This situation produces musical mediocrity. ${ }^{20}$ It is also possible that 'new' music composition has been stymied by the syndrome of the 'aberrant entrepreneur' (the term adapted from Gustafson and Ritzer) whose obsessive, self-interested, self-promoting behaviour could be implicated in the 
creation of inferior music given the modest amount of time he would be able to devote to perfecting his musical craft. ${ }^{21}$

Furthermore, the psychological literature suggests a connection between the behaviour patterns and personality traits of successful self-promoters and psychopaths. ${ }^{22}$ In their 1995 study, Gustafson and Ritzer argue that 'aberrant selfpromoters', like psychopaths, exhibit characteristics such as 'exploitativeness, entitlement, grandiosity, superficial charm, manipulativeness, need for dominance, lack of empathy and lack of guilt'. ${ }^{23}$ In their view the 'aberrant self-promoter' may not produce behaviour that is technically illegal but their primary motivation is to further their own self-interests. Such individuals have mastered leadership qualities but would be less inclined to be self-critical, especially of their own artistic endeavours.

With these issues in mind, I will evaluate the discourses of entrepreneurship, suggesting that a new conception of subjectivity that is marked by difference which is 'positive and productive, rather than negative and subtractive', a concept of difference 'which produces life itself, and enables the production of the new', has the potential to transform the field of music practice. ${ }^{24}$ The aim of this critique is to open a space for and to make viable that music traditionally silenced by the cacophony of entrepreneurial bluster. Ultimately, my aim is to open up the possibility for acting differently through making the present unthinkable. ${ }^{25}$

\section{-THE 'WOMAN COMPOSER' REVISITED}

Feminists who have made it their business to raise the profile of the 'woman composer' by arguing for difference, suggesting that women's music has aesthetic value of a different (but no less) kind from men's music ${ }^{26}$ have run into a barrage of criticism by their opposite number who reject this conception of difference as an impossible essentialist notion. ${ }^{27}$ This polemical opposition, which had been sparked notoriously by Susan McClary's book Feminine Endings, marked a significant moment in musicology, opening the floodgates for an outpouring that had never before been witnessed in the discipline. The 'sexual difference' camp, which also demonstrated the ways that music could be read as a cultural text, argued for the centrality of difference per se. The opposition to this idea, however, claimed that the 
work was exceedingly essentialist and suggested that social readings of music of any kind, in any case, are flawed because of music's abstract nature.

While this debate raged between the pages of various musicological journals in the 1990s, the proliferation of feminist work initially soared. ${ }^{28}$ At the turn of the twenty-first century, however, feminist work began to dwindle, seriously challenging the idea that musicology continues to have a feminist perspective. ${ }^{29}$ While it is possible that the identity of the 'woman' composer has become obscured by the remarkable array of scholarship on other marginal groups, without any of this work the identity of the female composer is potentially re-subsumed into the discourse of the male subject. Cusick shows how a feminist intervention can even disrupt 'the music itself' (for her, the 'ultimate feminist issue'), inscribing it as a site of multiple identities and experiences where previously 'the music itself' had powerfully sustained our complicity with the illusion that the 'ideal citizen' in music is the masculine, liberal individual. ${ }^{30}$

Like Braidotti, I am opposed to the hasty dismissal of sexual difference by those who are 'anti-essentialist' or who imagine that sexual discrimination was solved in the 1990s. Rather, a 'redefinition of female subjectivity in all its complexity' is needed in music. ${ }^{31}$ Before investigating how this could be achieved, I will explore how female subjectivity is constituted in the discourses of 'new' music practices currently. How do these discourses proselytise patterns of behaviour, producing a hegemony in which a whole body of practices and expectations are established?

\section{—DISCURSIVE FORMATIONS IN ‘NEW' MUSIC PRACTICES}

It would seem that the master-narratives, prevalent in modernist and positivist work in music research, have reinserted themselves into the discourses surrounding 'new' music performance. ${ }^{32}$ A product of neoliberalism, these masters' narratives are delivered to music in a double way. On the one hand, they give the appearance of being natural and neutral, impartial to particular interest groups. In this view, music is just that-music. There is no ideological agenda at work. On the other hand, these narratives are representative of a very small interest group, predicated on the idea that the group comprises exceptional musicians with an abundance of talent. At once it becomes possible to recognise how 'new' music is simultaneously viewed as 
neutral (that is, as autonomous and value-free) and exceptional (that is, as representative of a particular interest group).

It is useful to situate this discussion in what Lydia Goehr has termed the 'work-concept', for this would seem to have relevance to 'new' music today. ${ }^{33}$ According to Goehr, the 'work-concept' is a nineteenth-century phenomenon which conceives a musical work as a coherent entity. In the seventeenth and eighteenth centuries, the movements of a musical work would be broken up and frequently performed in isolation from the whole. In the nineteenth century, however, all the movements of a musical work were performed in entirety to an attentive (middleclass) audience who would passively listen in one concert sitting. The discourse of the 'work-concept' assumes that musical works of multiple movements are a unified, conglomerate of complex structures of sounds which, in turn, are intrinsically connected to a composer, a score and a set of given performance outlets. The 'workconcept' is perpetuated in the discourse of 'new' music practices in the current time. It is dependent upon the ideology of the hierarchy: first, it inscribes music with a fixed, essentialist identity tied to the composer; second, it assumes that certain types of music are superior.

The discourse of the hierarchy is a classic master-narrative. Its dualistic oppositions create subcategories of 'otherness' which are predicated on the assumption that to be 'different from', as Braidotti puts it, is to be 'less than' or to be 'worth less than'. ${ }^{34}$ The ideology of the hierarchy reduces difference to inferiority while reinforcing the superiority of the norm. Kalantzis and Cope have demonstrated how funding bodies adopt discriminatory 'vocabularies of excellence' to justify the funding of certain types of art-works. ${ }^{35}$ Similarly, Johnson argues that discourses about 'diversity' and 'nation' in Australian music are deeply rooted in the ideologies of class, gender and race. ${ }^{36}$ According to Johnson, key terms such as 'excellence', 'diversity' and 'Australian' are central to the Australia Council's platform: 'to promote excellence'; 'to foster the expression of an Australian identity by means of the arts'; 'to provide, and encourage provision of, opportunities for [all] persons to practice the arts'; 'to promote appreciation of the arts in the community', and 'to promote the general application of the arts in the community'. ${ }^{37}$ Johnson's problem is that if it were to achieve diversity, the composition of the Australia 
Council's boards and committees would need to radically change to avoid tokenism. ${ }^{38}$

The discourses of 'new' music, characterising it as 'complex' and 'difficult', infer that the music is aesthetically superior to popular music. It is promoted as such through the use of florid, descriptive language. The promotional material goes into overdrive to advocate the outstanding qualities of 'new' music, such as its capacity to rise above fleeting fashion impulses to touch the human soul, thereby having lasting, universal appeal. It is a discourse that sells 'new' music by championing its symbolic values, its ability to address life's existential questions. Composer biographies are tuned into these impulses. In one example, the composer asserts his music 'as an expression of the inner life (spiritual and emotional) in combination with a conscious intellectualism, which aims to express a life essence to an audience'. ${ }^{39}$ Similarly, a female composer claims her music to 'take people to inner spaces to discover, to reflect and be moved ... to entice listeners into revisiting vistas in their emotional home'.40 Likewise, the publicity material for another composer advertises his ability to create a 'unique sound world which seeks to reconnect music with elemental forces'.41 The languages of 'entrepreneurship' and 'visionary direction' characterised by unchallenged assertions about the worth of the music, appear in abundance in composer biographies and in discourses about 'new' music in general. The music is promoted as valuable. Its value is delivered by the marketing material rather than by a critical assessment of the music. Whether or not the music is really valuable is beside the point. This material labels the music as 'new' with the implication that it is progressive, unorthodox and transgressive. It is publicised as music associated with individual achievement and excellence. The discourses surrounding 'new' music echo those in the wider sphere concerned with human progress and biological essentialism. ${ }^{42}$

Braidotti argues that the "post-feminist" wave has merged with neoliberalism in gender relations', producing a mild effect of "gender trouble" in the social division of labour between the sexes'.43 In this view, the recent generations of the corporate world have paid lip service to 'gender mainstreaming' but without any acknowledgement of the collective past struggles of women. 'Gendermainstreaming' is argued to be an anti-feminist mechanism which, rather than closing the gap between male and female status, access and entitlement, increases it. 
In this master-narrative, the syndrome of the 'exceptional woman' is reintroduced, fostering 'a new sense of isolation among women and hence new forms of vulnerability'. ${ }^{44}$ In 'new' music, the 'exceptional woman composer' will be promoted and even celebrated. Australian composer, Moya Henderson (b. 1941), for example, had her career launched in the mid-1970s amid much media attention when it was announced that she would deliver a full-scale work based on Patrick White's Voss to Opera Australia. ${ }^{45}$ The media focused on Henderson's status as an 'exceptional woman': she was breaking into the male domain of opera; she had the temerity to obtain permission to write the opera from White, the 'literary Goliath in his den'; and she had recently renounced her Catholic faith by leaving her thirteen-year stint as a nun in the enclosed Sacré-Coeur order.46 Henderson was perceived to have broken a number of taboos worthy of mention in the Australian media and, in turn, this served the purpose of demonstrating she was 'exceptional'.

The culture of 'gender mainstreaming' is used by policy makers to assert power over individuals, making them conform by rewarding those who comply. Davies makes the point that it is 'typical of neoliberal discourse to obfuscate the issues in order to downplay the lines of force and thus reduce opposition, persuading those being shaped by the new order that they are conforming as a matter of their own free will'. ${ }^{47}$ To transpose this idea to music, practices associated with 'new' (implying freedom from 'old') music performance are regulated by a set of conventions which are self-perpetuating. There is a strong element of networking necessary for the production of 'new' music. An example could be a composer persuading a performance group and commissioning body to support the development of a 'new' work. From the commission through the composition to the performance, including its broadcast and recording, the 'new' work is generated out of a set of conventions to which the 'free' agent in the guise of composer must adhere in order to get her or his work performed. Given that the paradigm on which this music is produced seems to be replicated over and over again, however, the question also arises as to whether the music itself is being forced into old moulds and patterns, suggesting its conformity rather than distinctiveness.

Furthermore, female composers have frequently downplayed their gender in order to show that they are capable of writing music that conforms to the standards expected of them. McClary states that women composers 'were expected to write, 
think and perform, not just as well as, but in exactly the same ways as their male colleagues'.48 Paradoxically, the woman composer also believes her music expresses her 'personal identity' and thus conveys distinctive characteristics. This narrative constructs an image of the female composer that is similar to that of the male composer, transforming her music into the site of the 'ideal' citizen.

'New' music events will frequently combine performances of music with forums where the music is discussed by its composers. The forums are designed to give audiences insights into how composers think about their music, both in terms of its influences-extra-musical events, writings and other programmatic materialand its musical influences. At one such forum, a female composer was invited to speak about her music before a panel consisting of several male composers seated behind a barrier of tables. The female composer was strategically isolated on the stage and separated from them. This image, captured on a DVD, was striking, for in her singularity, she seemed vulnerable. In their number, they seemed powerful.

Maus has argued that discursive work on the 'music itself' is typically science-orientated. He suggests that the listener/theorist as feminine and passive has produced an anxiety-riddled 'top-down/bottom-up paradigm'.49 In such discourses, the composer is 'top-down' while the listener/theorist is in the passive supporting position, 'bottom-up'. This has led to the development of a 'penetrative masculinised' discourse in which the male listener/theorist is shown to 'think like a man'.50 Could there be an echo of the 'thinking like a man' discourse conveyed in forums such as the one I am describing? Arguably, the female composer's subject position seemed doubly 'feminised'. Firstly, she was the token 'woman' composer. Secondly, the interrogation of her music was from a 'top-down' perspective, casting her in the supporting role.

The gender mainstreaming discourse that produces the token 'exceptional woman' is evident in events such as this, serving to reinforce the exclusion of women from the audience, the public eye, and from music. Why is it that our creative artists now have to become performers who are publicly interrogated? Why are we as audiences so eager to create them as celebrities? ${ }^{51}$ What is concerning about the discourse of the 'celebrated individual' is the implicit assumption of a male identity as the 'bearer of creativity in music' which renders the female invisible. It is 
a discourse which reinvokes the nineteenth-century cult of the 'genius', dressing it up in the new languages of 'entrepreneurship' and 'visionary leadership'.

In the nineteenth century the artist was viewed as a pseudo-god whose art was understood to grow out of his individuality, in Christine Battersby's view, expressing a model of creativity which can only belong to the male artist. ${ }^{52}$ It presupposes an individual creator with a feminine brain who, in Schopenhauer's description, 'transcends the motivational desires and urges that are integral to masculinity, and acquires feminine passivity'. ${ }^{53}$ In this view, the 'genius' belongs to 'a kind of third sex-the female male'-and 'genius' equates with maleness whose usurping of feminine characteristics makes femaleness redundant. ${ }^{54}$ The typical neoliberal discourse, however, transforms this caricature of the 'genius' into an 'entrepreneur' and 'visionary leader.' The 'exceptional woman' is gathered up in this discourse to perform the work of 'gender mainstreaming'. Constituting the female composer as an individual with outstanding abilities, the discourse of 'gendermainstreaming' sends a signal of 'political correctness', which is to say it offers the token woman as the 'exceptional' example, proving that women can make it if they are good enough. Yet, regardless of how 'exceptional' the woman is, her success and ability have been shown to never quite measure up against the male 'norm'. 55

Exceptional talent is an attribute ostensibly belonging to a few, elite individuals. Publicity material forcefully promotes 'new' music in these terms, circulating it far and wide in brochures, newspapers, composer biographies, program notes, music reviews, grant applications, and online. An example of the kind of publicity material to which I am referring is posted on the New Music Network website to promote its 2008 season as follows:

New music is where creative musicians strive to express their ideas and feelings through media that encourage innovation and pose new challenges at every step. The pursuit of an aural ideal, the embrace of new technologies, the thrill of exploring a new combination of sounds or personalities, and the need to express a personal ethos are all motivating factors that encourage the creation of something new in music. This concert series reflects the wealth and diversity of new music, presenting Australia's leading exponents of contemporary art music performance ... The New Music Network concert series gives adventurous and inquisitive 
audiences the opportunity to connect and engage with the best of new music. ${ }^{56}$

In its exceptional line-up, 'improvisation with the bush' and 'the possibilities of intermedia and acousmatic computer works' are singled out. Individual composers and composer-performers are also highlighted, among them Elliott Carter and Cécile Broché (an 'exceptional woman'), the latter from Brussels playing electric violin. This publicity material of the network is a perfect illustration of a master-narrative, designed to seduce the unsuspecting music-lover into thinking she or he will experience some 'progressive' music while concealing the conventions involved in its marketing campaign and performance. It also produces an uncritical stance in the language used to sell the music as an 'excellent' product.

It is possible that participants and prospective concertgoers involved in this music enterprise would be unwittingly swept up by this hype-producing discourse. Yet, paradoxically, the implicit 'excellence' of the discourse could be, in reality, lacking in excellence. These discourses rarely define 'excellence' or explain how it is invoked as a criterion by which music is measured. Its meaning seems to be constructed by a privileged minority group who are motivated primarily by selfinterest in promoting their music. Further, this discourse relies upon a selfreplicating model in which the hierarchy of active/passive is invoked: an active composer or performer requires the presence of an inactive listener whose main function is to produce applause.

In the 'new' music scene, difference or 'newness' is defined in a very deterministic manner, characterised by a male persona which obscures the potentially interesting differences that could emerge if women's music were given more opportunities to be heard. Furthermore, the apparatus through which 'new' music performance in concert halls is constituted may mean it fails to produce anything new. My argument is that an overuse of musical or culturally saturated procedures, such as, to borrow McClary's words, 'the five-thousandth piece that impishly avoids tonic', reinforces what has become standardised practice. ${ }^{57}$ The same types of music are presented in the same types of venues (concert halls, for example) by the same types of musicians, and advertised with the same types of entrepreneurial language, over and over again. Such a discourse presupposes a central, individualistic (male) subject. Like Ellwood and Davies's proposition that we 
continue to live in a world in which the 'I' takes precedence while 'ignoring its embeddedness in relations with the 'you' who engages it', 58 the focus on the individual composer/performer in 'new' music ignores the 'other', effectively silencing audiences and women composers. The entrepreneurial subject conforms to the paradigm while oblivious to the fact that he or she is reproducing in endless amounts music which conforms to old, established patterns.

- IMPLICATIONS FOR THE FUTURE OF NEW MUSIC AND WOMEN'S MUSIC

Jacques Attali suggests that music has the potential to create new orders of 'noise' by introducing it as a prophetic element that disrupts the socius at strategic moments to produce new orders of noise. ${ }^{59}$ Such music does not enclose itself in the expectations of existing audiences but has the potential to generate a new audience. Drawing on Deleuze, Roffe says of such artistic practices:

art doesn't describe, represent or narrate the world, but literally creates new ways of experiencing the world; ways of feeling (affects) and perceiving (percepts) ... The work of art does not represent (or distort) the familiar world for the benefit of a pre-existing audience. Instead, in creating new ways of experiencing and living, artwork necessitates a new people, an audience that does not yet exist.60

According to Attali, however, as societies became increasingly industrialised, music began to be silenced through the mechanism of repetition: mass production, stockpiling and control by the music industry. ${ }^{6}$ ' $\mathrm{New}$ ' music replicates itself, repeating the same patterns and presentational formats. Does this mean that it fails to compose a 'new' order of noise?

Perhaps it does, for according to Kusek and Leonard, the new technologies of the digital revolution, which has given rise to the phenomenon of the musician as someone who has access to equipment rather than to training, poses a significant threat to classical music. ${ }^{62}$ While faced with the perilous situation of survival, however, the advocates for classical music, including those for the 'new' in the genre, continue to argue for its symbolic rather than economic capital.63 Yet, classical music has had to balance two seemingly conflicting positions: to live up to the ideals of excellence and individuality, and to yield a commercial profit. 
In Attali's view, the only hope for music is the invention of a new economy that empowers the listener as an operator, or the consumer as a producer. This is already occurring, indicated by Kusek and Leonhard and by the activities of organisations such as the Music Council of Australia. ${ }^{64}$ Here, bubbling under the surface of a rapidly fading 'new' music industry is a vibrant set of community-grown, music-making practices, many of which eschew the hierarchical model of 'excellence'. The implication that community music making is associated with women is drawn from an earlier source which demonstrates a model for music making practised by women in communities. This contrasts with concert hall music, which is focused on masterworks by individual composers. ${ }^{65}$ According to Solie, Drinker is interested in the whole context in which music is produced. She argues that Drinker's book 'is a history, not of works but of musical activities, of cultural practices', and draws attention to the binary divisions between the collective (associated with women) and the individual (associated with men), and between the professional (associated with men) and the amateur (associated with women) musician. ${ }^{66}$

Paying attention to the new trends cited above by Kusek and Leonard and drawing on models of practice established by women in previous eras, I will explore how it becomes possible to conceive the field of music practice, in a permanent state of flux, as a non-hierarchical, non-profit-making, non-individualistic, multidifferentiated model of interrelation. Such a model allows for Cusick's notion of a feminist, gender-conscious vision of music as 'double', 'triple', or 'multiple'.67 It enables the emergence of music hitherto 'unheard'. It potentially liberates us from the intellectual restrictions imposed on our experiences of music through the discourses of neoliberalism. In thinking through the implications of a 'new' music practice-and the 'becoming-imperceptible' of 'new' music-I shall utilise Braidotti's concept of 'activist nomad' and advance the notion of 'virtual feminine difference', conceiving it, to draw on Bonshek, as a 'receptivity to new "affects" or material-expressive instances of sensory force'.68 Such a conception of music has the capacity to produce variations and transformations. It considers the practices of music in terms of what they do or what they produce rather than what they signify or mean. 
—NOMAdIC ACTIVISM AND THE EETERRITORIALISATION OF 'NEW' MUSIC

The 'activist nomad' is a philosophical concept drawn from Deleuze and developed by Braidotti. ${ }^{69}$ It is an analytical device that opens up a space for thinking about the ways that subjects transgress boundaries and subvert conventions. According to Elizabeth Gould, nomadism 'includes a figuration that is at once metaphorical and embodied in an intellectual style and consciousness that suggests alternative subjectivities, making possible political agency in the context of fluid identities'.70 Applied to the institutional setting of 'new' music, the nomad performs a resistance to the authority of the conventions of music practice. The 'activist nomad' produces work that is both political and theoretical and becomes, in Deleuzian terms, the site of 'becoming-minoritarian', a concept that suggests movement away from the (male) norm.

While a Deleuzian framework avoids the determinism of neo-liberalist discourses, and hence implies that transformations can never be determined in advance, it is also possible to imagine that the smallest becoming can be revolutionary. Anna Hickey-Moody and Peta Malins outline a series of political becomings that have been proposed by Deleuze and Guattari as follows: 'a becoming-woman (to disrupt the dominant male form of subjectivity), becominganimal (to disrupt humanism), becoming-molecular (to disrupt the organization of the body), and becoming-imperceptible (to dismantle the idea of the self)'.71 Importantly, they point out that becomings are always at least double: 'they have the potential not only to affirm one's own capacity for change, but also to engender further becomings elsewhere'. ${ }^{72}$

How might an activist-nomadic intervention into the dominant, neoconservative discourses circulating around 'new' music practices make itself felt? The becoming-other of 'new' music entails moving away from the distinctiveness of the music towards something else while allowing for the insertion of women into its practices. It conceives a 'virtual feminine difference' in which women's music becomes provisionally distinctive. Such an image for 'new' music, then, imagines a set of practices that disrupt the dominant form of the music, imagining counterimages for the genre that would work against the grain of the 'aberrant' entrepreneurial, individual, neoliberal voice. It would attempt to formulate the ways 
in which the spaces of the rehearsal and the concert hall could be transformed by a conception of 'difference' as a productive concept.

A becoming of 'new' music, then, to draw on Claire Colebrook's parallel with language, would be its capacity to be transformed by 'other modes of becoming such as the becoming of organisms and social systems'. ${ }^{73}$ 'Becoming' is not conceived as an opposition to the stable world of 'being'. Becoming is a continuous flow. Life is a 'becoming-life', which in the process of becoming entails always being open to what it is not yet. The concept of 'becoming-imperceptible', drawing on Braidotti, has the potential to perform an 'absolute form of deterritorialisation' [destabilisation] of 'new' music through the 'process of becoming other-than-itself, suspended between the no longer and the not yet'. ${ }^{74}$ It performs a dismantling of the self, at strategic moments permitting virtual images of feminine difference in the guise of female composer to provisionally appear. In a Deleuzian framework, it becomes theoretically possible to regard the works of a female composer as affects of indeterminate moments of sensory force, connected with female bodies through the 'becoming-other' of the music. In this way, the music is connected to a social system in which the concept of a multi-differentiated and non-hierarchical subjectivity potentially transforms the field of 'new' music.

Some ideas for this new conception of music can be drawn from sources that have hitherto been invisible in the practice of musicology. Many of these writings talk about women's practices as community-based, suggesting that their value lies in the communal interrelationships that are established and developed between people who are actively assembled around music, playing, singing and composing. ${ }^{75}$ Such a notion for 'new' music potentially breaks down the barrier between 'active' musician and 'passive' audience. It suggests that not all music is remunerated.

\section{-CONCLUSION}

I have argued that 'new' music continues to replicate itself by being based on a set of outdated practices that presuppose the composing male entrepreneur as core. Such an individual competes in the same spaces for money and prestige with composers who could potentially deterritorialise the field of 'new' music, breaking it open by offering up new possibilities for the creation of music. The entrepreneurial performer is focused on the products created out of the already known and out of its 
masculinity. What would happen if music were composed out of its femininity and the unknown? In theorising this possibility, it is crucial that we avoid inverting the binary division between male and female. Such an idea is antithetical to Deleuzian thought whose concept of becoming removes the idea of the fixed, universal, egodriven individual. The concept of 'becoming' disturbs the old ways of thinking, opening up new modes of thought and practice.

In the institutions in which 'new' music is produced, a Deleuzian approach would question the ways that old practices are learnt and endlessly recycled through processes of deeply entrenched and repetitive actions. It would encourage the development of different practices that potentially create something new. What would the implications of such thinking be, not just for women in music but for music in general? How might we generate a musical space for becoming? This, in some ways, to recall Braidotti, is 'the philosophical question par excellence: it provokes and thus invites serious questioning'. ${ }^{76}$

Sally Macarthur is senior lecturer in musicology at the University of Western Sydney. She is author of Towards a Twenty-First Century Feminist Politics of Music (in press) and Feminist Aesthetics in Music (2002), and co-editor of Intercultural Music: Creation and Interpretation (2006) and Musics and Feminisms (1999).

\footnotetext{
-NOTES

${ }^{1}$ Gilles Deleuze and Felix Guattari speak about the necessity to disturb thought so as to avoid reproducing the known. In the spirit of Deleuze and Guattari, I am interested in how we might disturb the practices that have prevented women from fully participating as composers in 'new' music composition. See Gilles Deleuze and Felix Guattari, What is Philosophy?, trans. H. Tomlinson and G. Birchell, Columbia University Press, New York, 1994 (original work published in 1991).
} 
2 Two composers, Anton Webern (1883-1945) and Arnold Schoenberg (1874-1951), from the early twentieth century, exemplify the idea of music's historical necessity. Webern assumes that the history of music is evolutionary, a linear path that leads to the 'new' music in which his own unique contributions are situated. See Anton Webern, The Path to the New Music, trans. Leo Black in Willi Reich (ed.), Universal Edition, Vienna, 1960 and Theodore Presser, Pennsylvania, 1963. Schoenberg likewise unfolds the narrative of music's evolutionary path, placing himself in it as the revolutionary, heroic, 'lonely' figure. His music has never been widely embraced by audiences, yet it is justified because it is imagined to serve the interests of musical progress. See Arnold Schoenberg, 'How One Becomes Lonely' in Leonard Stein (ed.), Style and Idea, Faber \& Faber, London, 1975, pp. 30-53. Writing in the middle of the twentieth century, Milton Babbitt goes further to suggest that the audience is irrelevant to the composer, stating that a 'private life of professional achievements' is far more desirable than 'a public life of unprofessional compromise and exhibitionism'. See Milton Babbitt, 'Who Cares if You Listen?', High Fidelity Magazine, vol. 8, no. 2, February 1958, p. 126. 'New' music is considered 'difficult', a notion which is carried forward into the twenty-first century. See, for example, advertisements for electronic music at <http://www.discogs.com/release/756249> and at <http://www.auricular.com/auricular2/index.shtml>. Other examples include composers staging projects designed to include audience participation in the performance of 'difficult music' - see, for example, <http://www.machineproject.com/difficult/>-and the language adopted by reviewers suggestive of the music's difficulty. See, for example, a review of Australia's Elision Ensemble in 2002 which reads as follows: 'Theatrically lit and positioned among and above the audience, Elision's fourteen virtuoso musicians pummel out an immersive electro-acoustic sound field for close on two hours, drenching all present in everything from high-end guitar caterwauling and dog whistles to stabs of electronic feedback, subtle viola and cello phrases, free-jazz saxophone, amplified styrofoam scratchings and the destruction of instruments.' Mark Gomes, Courier Mail, 9 July 2002.

${ }^{3}$ It may be the case that 'new' music has 'softened' under postmodernism, particularly music which has reintroduced tonality (for example, 'minimalist' music) or experimented with different presentation formats and contexts (such as being played in natural environments like the bush, or in the desert of outback Australia, or in a dawn chorus 'event' by the sea, the latter of which was included in the Sydney Philharmonia Choir's offering to the 2009 Sydney Festival), or included a range of other media, or drawn popular music into its domain. Indeed, Robert Fink has recently argued that in addition to the serial hegemony there has been an intensification of an emergent tonal mainstream that has its roots in minimalist music. See Robert Fink, '(Post-)minimalisms 1970-2000: The Search for a New Mainstream' in Nicholas Cook and Anthony Pople (eds), The Cambridge History of Twentieth Century Music, Cambridge University Press, Cambridge, 2004, 539-56. Despite these developments, my argument is that little has changed in 'new' music. The music depends on the centrality of the male, entrepreneurial composer. Such a composer will often self-consciously seek out the 'new' while 'reinventing the wheel', 
in one recent example reintroducing Kagelian-like music theatre as if it was being presented for the first time.

4 Susan McClary draws attention to this idea in her critique of 'new' (difficult) music. See Susan

McClary, 'Terminal Prestige: The Case of Avant-Garde Music Composition', Cultural Critique, Spring 1989, pp. 58-62.

${ }^{5}$ Dusman argues that this is the reason why 'new' music lacks an audience. See Linda Dusman,

'Unheard-of: Music as Performance and the Reception of the New', Perspectives of New Music, vol. 32, no. 2, Summer 1994, pp. 130-47.

${ }^{6} \mathrm{~A}$ 'good' crowd for this kind of music could number around two hundred people. This number will increase marginally or decrease significantly depending on how well the marketing campaign has managed to promote the music. Since practitioners comprise a large part of the audience, it is inevitable that the audience becomes a powerful site in which 'new' music and its practices are reproduced. I have attended 'new' music concerts on occasions with composer-colleagues and have found them eager to hear the music of their colleagues so that that they are informed of any 'new' developments which they then might imitate or further extend.

${ }^{7}$ As McClary points out, however, at the turn of the twentieth century 'avant-garde' referred to a 'model of culture in which artists served as the advanced guard for social progress: artists who rallied around the term were committed to a project of ongoing liberation and viewed their work as helping to further their political goals. This project began to crumble in the aftermath of World War I, when the term was increasingly appropriated by the opposite camp-the artists who wanted to withdraw fastidiously from society and politics'. See Susan McClary, 'Response to Linda Dusman', Perspectives of New Music, vol. 32, no 3, Summer 1994, p. 153.

8 McClary, 'Response to Linda Dusman', p. 148.

9 McClary, 'Response to Linda Dusman', p. 149.

10 See McClary, 'Terminal Prestige', pp. 57-81. McClary contextualises her discussion of 'new' music by drawing on Laurie Anderson's satirical 'take' on 'Difficult Music' in United Sates, part II, Warner Bros Records Inc., 1984. Here, according to McClary, Anderson welcomes the listener to 'Difficult Listening Hour', suggesting that it is the 'spot on your dial for that relentless and impenetrable sound of Difficult Music' ... 'So sit bolt upright in that straight-backed chair, button that top button, and get set for some difficult music: Ooola', p. 57. While McClary's portrayal is of the 'new' music scene as it was some twenty years ago, I argue that the situation is not too dissimilar from how it is today, noting that this phenomenon is eroded to some extent by the introduction of so-called postmodernist 'tonal' musical works into the mix.

11 McClary, 'Response to Linda Dusman', p. 148.

12 McClary, 'Response to Linda Dusman', p. 148.

13 Ashley Woodward, 'Deleuze and Suicide' in Anna Hickey-Moody and Peta Malins (eds), Deleuzian

Encounters: Studies in Contemporary Social Issues, Palgrave Macmillan, Houndmills UK, 2007, pp. 62-75. 
14 McClary, 'Response to Linda Dusman', p. 148.

15 During a short-lived period in the early 1990s, women's 'new' music enjoyed a moment of recognition by being more extensively programmed in 'new' music concerts. My survey of 'new' music performance in Australia from 1985 to 1995 shows a steady increase in the performance of women's 'new' music: measured as a category of 'new' music it rose from approximately 4 per cent in 1985 to approximately 13 per cent in 1994 before plunging to approximately 5 per cent in 1995 . This increase is attributed to the Women Composer's Network founded by composer Mary Mageau, which had been lobbying federal government representatives to intervene in the programming of performance groups which received public funding. The folding of the network led to a commensurate drop in the amount of women's music being performed. See Sally Macarthur, Feminist Aesthetics in Music: Politics and Practices in Australia, PhD thesis, University of Sydney, 1997, pp. 41-85.

16 These statistics refer to all music performed, including that of historic music. They are skewed because of the inclusion of the historical canon. With the canon eliminated, and the amount of women's music performed measured against recent Australian music, a healthier picture is given but, as my data show, there has been a decline from 1985 where women's music constituted 15 per cent of the Australian music performed to 8 per cent in 1995 to 7 per cent in 2005. See Macarthur, 'Feminist Aesthetics in Music'; Sally Macarthur, Feminist Aesthetics in Music, Greenwood Press, Westport, Connecticut, 2002; Sally Macarthur, 'Raising the Platform for Women', Music Forum, vol. 12, no. 2, 2006, pp. 40-3; Jennifer Fowler, 'Where are the Women?', Music Forum, vol. 13, no. 1, 2006-2007, pp. 24-5; and Lisa Hirsch, 'Lend Me a Pick Ax: The Slow Dismantling of the Compositional Gender Divide', New Music Box, 14 May 2008, <http://www.newmusicbox.org/printerfriendly.nmbx?id=5576>.

17 Sally Macarthur, 'Gender and the Tertiary Music Curriculum in Australia', in Catherine Grant (ed.), Music in Australian Tertiary Institutions: Issues for the 21st Century, 2007, <http://www.nactmus.org.au/NACTMUS2007/musical_culture_of_australia.html>,pp. 1-38. ${ }^{18}$ According to Hirsch women comprise about 30 per cent of students studying musical composition in North American music institutions. See Hirsch, 'Lend me a Pick Ax'. Women composers represented by the Australian Music Centre (AMC) have increased from 8 per cent in the 1980s to 14 per cent in the mid-to-late 1990s to 25 per cent in 2008, up by 1 per cent from data gathered in 2007 (data provided by the AMC).

${ }^{19}$ See Rosi Braidotti, Nomadic Subjects: Embodiment and Sexual Difference in Contemporary Feminist Theory, Columbia University Press, New York, 1994 and Rosi Braidotti, Transpositions, Polity, Cambridge and Malden, USA, 2006.

20 Richard Toop, 'Discourse: Muffled, Muted, Muzzled?', Sounds Australian: Journal of the Australian Music Centre, vol. 67, 2006, p. 42.

21 Sigrid B. Gustafson and Darren R. Ritzer, 'The Dark Side of Normal: A Psychopathy-linked Pattern Called Aberrant Self-promotion', European Journal of Personality, vol. 9, 1995, pp. 147-83. 
22 See T.J. Harpur, A.R. Hakstian and R.D. Hare, 'Two-factor Conceptualization of Psychopathy: Construct, Validity and Assessment Implications', Psychological Assessment Journal of Consulting and Clinical Psychology, vol. 1, 1988, pp. 6-17; T.J. Harpur, and R.D. Hare, 'Self Report of Psychopathy, II', Unpublished instrument, 1989 cited in Gustafson and Ritzer.

23 Gustafson and Ritzer, p. 148.

${ }^{24}$ Anna Hickey-Moody and Peta Malins (eds), Deleuzian Encounters: Studies in Contemporary Social Issues, Palgrave Macmillan, Houndmills UK, 2007, p. 5.

25 Michel Foucault, 'Interview with Michel Foucault' in J.D. Faubion (ed.), Michel Foucault: Power, New York Press, New York, 2000.

${ }^{26}$ See Eva Rieger, 'Dolce semplice?': On the Changing Role of Women in Music', in G. Ecker (ed.),

Feminist Aesthetics, trans. H. Anderson, The Women's Press, London, 1985, pp. 135-49; Eva Rieger, 'I

Recycle Sounds: Do Women Compose Differently?', Journal of the International League of Women Composers, March 1992, pp. 22-3; Susan McClary, Feminine Endings: Music, Gender, and Sexuality, University of Minnesota Press, Minneapolis and Oxford, 1991; Marcia Citron, Gender and the Musical Canon, Cambridge University Press, Cambridge, 1993; Ellie M. Hisama, Gendering Musical Modernism: The Music of Ruth Crawford, Marion Bauer, and Miriam Gideon, Cambridge University Press, Cambridge, 2002; and Macarthur, Feminist Aesthetics in Music.

27 See Elaine Barkin, 'either/other', Perspectives of New Music, vol. 30, no. 2, 1992, pp. 206-33; Pieter C. Van den Toorn, 'Politics, Feminism, and Contemporary Music Theory', The Journal of Musicology, vol. 9, no. 3, 1991, pp. 257-99; Paula Higgins, 'Women in Music, Feminist Criticism, and Guerilla Musicology: Reflections on Recent Polemics', 19th Century Music, vol. 27, no. 2, 1993, pp. 174-92; Elizabeth Sayrs, 'Deconstructing McClary: Narrative, Feminine Sexuality, and Feminism in Susan McClary's Feminine Endings', College Music Symposium: Journal of the College Music Society, 1993-94, pp. 33-4 and pp. 4155; Peter J. Martin, Sounds and Society: Themes in the Sociology of Music, Manchester University Press, Manchester and New York, 1995, pp. 148-61; and Mary Kay Temple, 'War Inna Babbelogue', The Musical Times, vol. 135, no. 1841, July 1996, pp. 5-9.

28 See Jane Bowers and Judith Tick (eds.), Women Making Music: The Western Art Tradition, 1150-1950, University of Illinois Press, Urbana and Chicago, 1986; McClary, Feminine Endings; Karin Pendle (ed.), Women and Music: A History, Indiana University Press, Bloomington and Indianapolis, 1991; Citron, Gender and the Musical Canon; Susan C. Cook and Judy J. Tsou (eds), Cecilia Reclaimed: Feminist Perspectives on Gender and Music, University of Illinois Press, Urbana and Chicago, 1994; Lucy Green, Music, Gender, Education, Cambridge University Press, Cambridge, 1997; Sally Macarthur and Cate Poynton (eds), Musics and Feminisms, Australian Music Centre, Sydney, 1999; and Hisama, Gendering Musical Modernism.

${ }^{29}$ See Suzanne Cusick, 'Performing/Composing/Woman: Francesca Caccini meets Judith Butler' in Sally Macarthur and Cate Poynton (eds), Musics and Feminisms; and Sally Macarthur, 'A Thousand 
Dissonances: Music Research and the Nomadic Female Composer', Australian Feminist Studies, vol. 24, no. 59, March 2009, pp. 53-69.

30 Suzanne Cusick, 'Gender, Musicology and Feminism' in Nicholas Cook and Mark Everist (eds.),

Rethinking Music, Oxford University Press, Oxford \& New York, p. 496.

${ }^{31}$ Rosi Braidotti, Nomadic Subjects: Embodiment and Sexual Difference in Contemporary Feminist Theory, Columbia University Press, New York, 1994, p. 149.

32 See Sally Macarthur, 'A Becoming-Infinite Cycle in the Music of Anne Boyd', Radical Musicology, vol. 3, 2008, <http://www.radical-musicology.org.uk>, 17 May 2009, 54 pars.

33 Lydia Goehr, The Imaginary Museum of Musical Works: An Essay in the Philosophy of Music, Clarendon Press, Oxford, 1992. While some postmodernist hybrid forms, such as those which cross into disciplines other than music (such as installations, performance art, radiophonic work, and music theatre), may be inclined to erode the idea of the 'work-concept', the focus in this essay is to music which is performed in traditional venues such as the concert hall. In this context, I argue that the 'workconcept' is applicable to modernist and postmodernist music. Further, the context is an important indicator of the degree to which music subverts its conventions. In the concert hall (and the academy, for that matter), I argue that 'new' music is less inclined to be subversive. It is also the case that the differences between modernist and postmodernist music-the former, perhaps, championing an aesthetic which as I argued earlier is deemed complex and difficult, and the latter being easier on the ear in simplifying the musical language, sometimes reducing melodic and harmonic material to triadic tonality-is not always, if ever, a clear separation. Indeed, to argue for this distinction, like others mentioned in this essay, is to perpetuate the binary culture which I am attempting to dissolve.

34 Braidotti, Nomadic Subjects, p. 147.

35 Mary Kalantzis and Bill Cope, 'Vocabularies of Excellence: Rewording Multicultural Arts Policy' in Sneja Gunew and Fazal Rizvi (eds.), Culture, Difference and the Arts, Allen \& Unwin, Sydney, 1994, pp. 13-34.

36 Bruce Johnson, Creative Nation, Creating Nation: Issues in Cultural Policy and Popular Music, unpublished paper delivered at the IASPM Australia-New Zealand conference, 1995.

37 See section 5, Australia Council Act, Australia Council Annual Report 1994-95, p. 4.

38 While Johnson's report may seem dated, it is likely that the membership of important committees and boards at the council has not radically altered. It is more than likely the case that the dominant membership represents males of white, Anglo-Saxon background, thus conspicuous for its lack of diversity to be found in Australia.

39 Bruce Crossman, 'Australian Composer Biography', Australian Music Centre, <http://www.amcoz.com.au/composers/>.

40 Becky Llewellyn, 'Australian Composer Biography'. Australian Music Centre, <http://www.amcoz.com.au/composers/>.

${ }^{41}$ Ross Edwards, 'Biography', G. Ricordi and Co, London, <http://www.ricordi.co.uk/>. 
42 Braidotti, Transpositions.

43 Braidotti, Transpositions, p. 45.

${ }^{44}$ Braidotti, Transpositions, p. 45.

45 Patrick White, Voss, Penguin Books, Middlesex, England, 1960.

46 The literary Goliath was Patrick White. See Geraldine Pascall, 'Moya Gets the Go-ahead to do Voss Opera', Australian, 29 November 1973, p. 3.

47 B. Davies, 'Legitimation in Post-critical, Post-realist Times, or Whether Legitimation?' in Paul Hart (ed.), Sage Companion to Research, Sage, London (in press), p. 8.

48 Susan McClary, 'Different Drummers: Theorising Music by Women Composers' in Macarthur and Poynton (eds), Musics and Feminisms, p. 80.

49 Fred Everett Maus, 'Masculine Discourse in Music Theory', Perspectives of New Music, vol. 13, no. 2, Summer 1993, pp. 264-93.

50 Maus.

${ }^{51}$ A parallel can be drawn here with celebrity writers who are required to attend signings, launches, interviews, and panel discussions when they publish their latest books.

52 Christine Battersby, Gender and Genius, Indiana University Press, Bloomington and Indianapolis, 1989, pp. 44-5.

53 Battersby, p. 107.

54 Battersby, pp. 106, 107.

55 See A. McArthur, 'Women and Originality', Etude, vol. xx, no. 2, February 1902, p. 32; G.T. Ladd, 'Why Women Cannot Compose Music', The Yale Review, vol. 6, no. 4, July 1917, pp. 789-806; C.E. Seashore, 'Why No Great Women Composers?' in In Search of Beauty in Music: A Scientific Approach to Musical Aesthetics, Ronald Press, New York, c.1947, pp. 363-7 and J. Rubin-Rabson, 'Why Haven't Women Become Great Composers?', High Fidelity/Musical America, vol. xxiii, no. 2, February 1973, pp. 47-50. The sentiments expressed by these earlier writers has been critiqued by E. Gates, 'Why Have There Been No Great Women Composers? Psychological Theories, Past and Present'. Journal of Aesthetic Education, vol. 28, no. 2, Summer 1994, p. 27 and McClary, Feminine Endings; Citron, Gender and the Musical Canon; and Macarthur, Feminist Aesthetics in Music.

56 James Nightingale, 'Launching the 2008 New Music Network, 2008,

Series',<http://www.newmusicnetwork.com.au/>. Italics my emphasis.

57 McClary, 'Response to Linda Dusman', p. 148.

58 C. Ellwood and B. Davies, 'What Counts as Bullying? Questions of Intentionality, Relations of Power and Repetition, Qualitative Research in Psychology (in press), pp. 16-17.

59 Jacques Attali, Noise: The Political Economy of Music, trans. Brian Massumi, Foreword by Frederic Jameson, Afterword by Susan McClary, Manchester University Press, Manchester, 1985 (Presses Universitaires de France, 1977). 
${ }^{60}$ Jonathon Roffe, 'The Revolutionary Dividual', in Hickey-Moody and Malins (eds), Deleuzian Encounters, p. 44

61 Attali.

62 David Kusek and Gerd Leonhard, The Future of Music: Manifesto for the Digital Music Revolution, Berklee Press, Boston, 2005.

63 While arguing for a difference in function between classical and popular music, Julian Johnson draws attention to this debate which polarises the music in terms of its symbolic versus economic value. See Julian Johnson, Who Needs Classical Music? Cultural Choice and Musical Value, Oxford University Press, Oxford and New York, 2002. Others are wedded to the idea that classical music should be valued for its aesthetic qualities. See Ivan Hewett, Music: Healing the Rift, Continuum, New York and London, 2003; Joshua Fineberg, Classical Music, Why Bother? Hearing the World of Contemporary Culture through a Composer's Ears, Routledge, New York and London, 2006; and Lawrence Kremer, Why Classical Music Still Matters, University of California Press, Berkeley, Los Angeles and London, 2007.

64 Kusek and Leonhard. Music Council of Australia, <http://www.mca.org.au/>.

65 See Sophie H. Drinker, Music and Women: The Story of Women in Their Relation to Music, Zebger, Washington, DC, 1977 (first edition, 1948).

66 See Ruth A. Solie, 'Sophie Drinker's History' in Katherine Bergeron and Philip V. Bohlman (eds), Disciplining Music: Musicology and Its Canons, University of Chicago Press, Chicago and London, 1992, p. 29.

67 Cusick, 'Gender, Musicology and Feminism'.

${ }^{68}$ Corrina Bonshek, Australian 'Deterritorialised' Music Theatre: A Theoretical and Creative

Exploration, PhD thesis, University of Western Sydney, 2007, p. 3.

${ }^{69}$ Braidotti, Transpositions.

70 Elizabeth Gould, 'Feminist Theory in Music Education Research: Grrl-illa Games as Nomadic Practice (or How Music Education Fell from Grace)', Music Education Research, vol. 6, no. 1, March 2004, p. 68.

71 Hickey-Moody and Malins (eds), p. 6.

72 Hickey-Moody and Malins (eds), p. 6.

73 Claire Colebrook, Gilles Deleuze, Routledge, London and New York, 2002, p. 4.

74 Braidotti, Transpositions, p. 156.

75 See Drinker, Music and Women; Solie, 'Sophie Drinker's History'; and Cusick, 'Gender, Musicology and Feminism'.

76 Braidotti, Transpositions, p. 10. 